\title{
Evaluation Study of the Small and Medium Business Assistance Program to Increase the Life of the Community-Based People
}

\author{
Anan Sutisna, Arifal Isnain Herginanto
}

\begin{abstract}
This study aims to describe the success of the mentoring program in improving the livelihood of communitybased people of small and medium enterprises which incorporated in the Self-Help Groups (KSM). This mentoring activity has a strategic role. Therefore, it needs to be carefully evaluated by using Context, Input, Process and Product (CIPP) model. The method used in this study is survey with descriptive technique, where the subjects are thirty two small and medium traders who are the members of the Self-Help Groups or KSM. The data collection techniques are Questionnaires and Interviews, where the research instrument is developed based on the context, input, process and product components. The results show that (1) $78 \%$ of the context component is appropriate, (2) $78 \%$ of the input component is measured appropriate, (3) $88.5 \%$ of the process component is appropriate, and (4) $76 \%$ of the product component is also appropriate. Hence, the small and medium business assistance program in increasing the life of the community-based peoplein CipinangMuara, East Jakarta, was held effectively with an average of $80.1 \%$ based on the CIPP evaluation model.
\end{abstract}

Keywords: $\quad$ Evaluation of CIPP model program, SME assistance

\section{INTRODUCTION}

Uneven public welfare is one of the main problems in Indonesia. Not only in the village areas, but in the urban areas also, there are still many community members who live in unfavorable condition due to poverty factor. In urban areas, particularly, poverty conditions are urgent to address. This condition is caused by some aspects such as the low availability of employment, the lack of access to adequate basic facilities and infrastructure, the quality of housing and settlements that are far out of the feasibility standard, as well as the uncertain livelihoods.

In Indonesia, the unprosperous population with the spending per month under the poverty line is as many as 27,73 million people or $10.9 \%$ in 2014 . Then, it increased to $11.22 \%$ or 0.82 million people in 2015 with the total 28.59 million people (BPS, 2015). This can not be separated from the role of food commodities against the poverty line that is much greater than the role of non-food commodities (housing, clothing, education, and health). Therefore, the poverty percentage index from 2014 to 2015 still tends to increase.

In addition, at the beginning of 2016, the entry into the force of ASEAN Economic Community (MEA) was officially opened. In the MEA itself is applied free flow among the ASEAN fellow countries which includes: (1) Free flow of goods, (2) Free flow of services, (3) Free flow of skilled labor, (4) free flow of capital and (5) Free flow of investment. These five state that every person of ASEAN member country is free to work, and to conduct business in every ASEAN country.Then, every country including Indonesia has an equal opportunity to do so. This also causes the competition level in the professional and business fields become more stringent. With the condition of poverty in Indonesia that increases and barely to be overcome, in fact, Indonesia is still not ready to face the MEA.After all, the Human Development Index in Indonesia is also still very weak.

Various alternative solutions have been created by the government. One of them is by launching the National Program of Urban Community Empowerment (PNPM Mandiri Urban) in 2007 which since April 2015 has changed its name to Urban Poverty Program (P2KP). P2KP is implemented with the aim of achieving sustainable improvement of the welfare of the poor through a process of community empowerment. As for the implementation, it applies an institutional strengthening approach at the basic level called the Self-Helping Society or (BKM / LKM).

With the establishment of the body, in fact, to encourage the emergence of new entrepreneurs, as it is actually the entrepreneurial process of creating something different by devoting all the time and energy accompanied by financial, psychological, social responsibility, and receiving 
compensation in the form of money and personal sattisfaction. (Alma: 2009).

Community Self-reliance Agency as a forum for the struggle of the poor in voicing their aspirations and needs as well as locomotive poverty alleviation that run independently and sustainably by the society has not become a solution for entrepreneurship. Rather, the BKM / MFI is formed and elected by the community through direct elections, and the members of the BKM / LKM governance structure are the members of the community itself.

With the main objective to improve the welfare of community members in accordance with the true meaning within the scope of social welfare as a condition that must meet three main requirements, namely (1) when the social problems can be managed properly; (2) when the needs are met; and (3) when the social opportunities are fully opened. (Huda: 2009)

In an effort to realize the goal, one of the program components implemented is Community-Based Livelihood Improvement (PPMbK). Community-Based Livelihood Improvement Program (PPMBK) is an intervention in the development of community productive activities that directly improve the livelihood of the poor by a non-governmental group approach. Therefore, the assistance is focused on strengthening the business development undertaken by SHGs.

According to Sumodiningrat, assistance is: "Activities that are believed to be able to optimally encourage the empowerment of the indigent poor. In accordance with their duties, counselors should position themselves as the planners, the mentors, the informers, the motivators, the facilitators, and the evaluators simultaneously. (Sumodiningrat: 2009). Such objectives can be attained thoroughly through techniques and methods with the intention of allowing individuals, groups, and communities to meet their needs and solve their adjustment problems to changing patterns of society, as well as through cooperative action to improve the economic and social conditions. (Suud: 2006)

Under these conditions, the establishment of an MFI in the CipinangMuara area is also a venue to overcome poverty and provide learning for the local community with a Direct Community Support stimulant. In addition, the MFI acts as a decision maker or policy, and as an assessments, supervision, and programmingconductor of the problems faced by KSM. It is even clear that mentoring is an activity that has three main objectives, namely: (1) To develop individuals within an organization or group, (2) To perform targeted actions in order to achieve the objectives, and (3) To make continuous improvement (Homan \& J Miller: 2008).

Thus, a program to assist small and medium enterprises to improve the livelihood of community-based people needs to be evaluated. Djudju suggested that understanding of program evaluation is the process of systematic determination of the value, purpose, effectiveness, or suitability of something in accordance with predetermined criteria and objectives. The decision-making process is based on the detail comparisons of the observed data using certain predefined standards (Sudjana, 2009).

In Tognolini's study of standards based on evaluation to expand the budget and expansion of the educational system suggests that the use of evaluation in education leads to increased human capital and educational expansion (Tognolini et al .: 2007). While the results of the study Christie mentioned why community-based assessment is not a universal feature of a high-stakes assessment system. There are three reasons: (1). Contraction between psychoanalytic and evaluation functions (2). Impacts of different schools or communities and (3).Assessment of teachers or counselors. (Christie: 2009)

There are other opinions that portfolio assessment can meet the demands of psychometric reliability, (Johnson, McDaniel, and Willeke: 2000). agrees: "As the differences end, the growing middle ground is increasingly filled with new approaches to unite us, like a realistic evaluation." Datta (2001: 405). Although a treatise from realistic evaluation is beyond the scope of this artilkel, it is an important contribution worth examining further. So far, no article has reported the application of this philosophy to program evaluation. Time will tell whether the emerging realism will happen in the field. Regardless of the ongoing paradigm war, which tends to polarize the field between two alternatives (objectivist or constructivist assumptions, quantitative or qualitative methods, summative or formative goals), the literature indicates an increasing popularity of pragmatic strategies (Bengston\& Fan, 1999; Pratt et al. 2000).

Hence, it can be concluded that program evaluation is an effort to collect information about a program, activity, or project. Such information is useful as a decision maker, 
among other things to improve the program, refine the program activities, and further, to stop an activity or disseminate ideas that underlie theprogram or the activity. The information collected should meet the scientific, practical, and appropriate requirements of the underlying value in any decision-making.

Educational evaluation is applied to identify student achievement and diagnose educational outcomes, and play an important role in improving the quality of education. It is considered an ongoing process and is set to describe, guide and ensure the quality of education. The results of Jahanian, R, showed that educational evaluation has different functions and applications, some of which are introduction, syllabus revision, comparison and demand analysis. (Jahanian, R: 2012)

This is what draws the attention of researchers to know the effectiveness of business assistance programs for CommunityBased Livelihood Improvement (PPMbK) as a group of small and medium enterprises incorporated in the KSM. Therefore, the research question is "Is the Community-Based Livelihood Improvement Program effective for helping the small and medium entrepreneurs in CipinangMuara, East Jakarta?"

\section{RESEARCH METHODOLOGY}

\subsection{Research objective}

This research was conducted to examine the extent of effectiveness of PPMbK business assistance program (Community Based Livelihood Improvement) conducted by P2KP Facilitator in order to increase the livelihood of micro and middle business actors who are the members of Self-Help Groups.

\subsection{Time and Place of the Research}

This research was conducted from February until December 2016 in DKI Jakarta Province, specifically in CipinangMuara, East Jakarta Administration City.

\subsection{Research Method}

Research method is a scientific way to obtain data with a specific purpose and usefulness (Sugiyono: 2010). Research method is also defined by Mc. Millan and Schumer in the book of Research in Education "Research method that is, how to collect and process data that developed to gain knowledge or answer to the problem through reliable procedures (Hadeli: 2006).

Evaluative research is an evaluation design in collecting and analyzing data systematically to determine the value or benefits of an educational practice. Evaluative research also aims to determine the implementation of policies, not only on the conclusions whether they have been implemented well or not, but also to know the advantages and disadvantages of the program implementation. The researcher is an evaluative research with Context, Input, Process, Product (CIPP) model which intends to collect data on policy implementation, as well as as the input for the organizer of business improvement program for the Community-Based Livelihood Improvement (PPMbK).

Survey method can be part of descriptive method, and used in evaluation by collecting data from sample by using data collection instrument that is questionnaire and / or interview, so that data processing result can represent a relatively large number of population (Sudjana: 2008).

\subsection{Population dan Sample Collecting Technique}

Population here refers to the whole subject of the study. (Suharsimi: 2010). According to Ary et.al in the book of Research Methodology of Education, Competence and Practice, population is well defined as class of people, events, or objects (Sukardi: 2003). The study population is the membersliving together in one place and planned to be the target of the conclusion of the research result.

The population of this research is program organizers, small entrepreneurs who are members of Self-Help Groups and facilitators who are involved in the Community Based Livelihood Improvement program (PPMbK) in CipinangMuara, East Jakarta consisting of 32 traders joined in SelfHelp Groups (KSM), with 1 facilitator and 1 person in charge.

Sampling in this study was conducted on the basis of purpose or commonly called purposive sampling because to determine a person to be a sample or not, it should be 
based on a particular purpose. And this study focused on the traders / small business actors who are members of the Self-Help Groups (KSM). Since the business assistance program has the goal to improve the welfare of the traders or business actors, 32 persons as the total sample are chosen to know the success of the program.

\subsection{Isntrument dan Collection Technique}

Instrument research is a tool or facility used by researchers in collecting data. In order to make the work easier and the results better and more accurate, a complete and systematic instrument is recommended so that the data is more easily processed. One of the research instrument objectives is to obtain complete data and information on the objects being studied. Based on the stages of the activities in this study, the instrument used is written as follows:

\section{Interview}

An interview is a dialogue conducted by the interviewer to obtain information from the interviewee used to assess a person's circumstances. In this technique the researcher asks something that has been planned to the respondent. The results were recorded as important information in the study.

\section{Questionnaire}

Questionnaire is a list of statements or questions sent to the respondents, either directly or indirectly (post or intermediary) (Husaini\&Purnomo: 2011). And also questionnaires are written questions that are used to obtain information from the respondents.

\subsection{Data Analysis Technique}

Data analysis is the process of searching and compiling the data obtained from interviews, notes, field and documentation. This can be accomplished or donethrough organizing data into categories, describing into units, synthesizing, arranging into patterns, choosing which fund is important, and making conclusions in order to be easily understood by self or others.

The data obtained from questionnaires were analyzed using percentage technique. The steps undertaken include the data obtained are prepared based on the questions and answers given then precentaged by using the following formula:

Explanation:

$$
P=\frac{\sum X}{N} \times 100 \%
$$

$\begin{array}{ll}\mathrm{P} & =\text { Precentage } \\ \Sigma \mathrm{X} & =\text { Respondents' total answer } \\ \mathrm{N} & =\text { Respondents number }\end{array}$

The criteria used in this study are the unquestioned quantitative criteria. This criterion is composed only with observing regardless of what is done by dividing the numbers. Here are the evaluation criteria (Anan \& Rica 2010).
$0 \%-20 \%$
$21 \%-40 \%$
: Inappropriate
$41 \%-60 \%$
$61 \%-80 \%$
: Less appropriate
: Quiteappropriate
$81 \%-100 \%$
: Appropriate
: Very appropriate

\section{RESEARCH FINDINGS AND DISCUSSION}

\section{Data Description}

Evaluation result data in the business improvement program for the CommunityBased Livelihood Improvement in CipinangMuara, East Jakarta, is viewed from the context component or the background of activities, and the purpose of the activity. Input or matters relating to how to use the resources used to achieve the program objectives. Then, process or how the activities are implemented. And, product or results or benefits received by the program objectives, referring to the CIPP evaluation model developed by Stuflebeam.

CIPP component data is obtained through questionnaire which is an assessment sheet addressed to the respondent that is focused on KSM members ie business actors who parts of the 32 people as the target of the program. It is alsoobtained through interviews to the Assistant Coordinator of P2KP of East Jakarta and KepulauanSeribu'sFinancial Management. As from the organizers amounted to one person, as well as the volunteers from Community Self-Reliance Institute (LKM) CipinangMuarais also one person as a supporting research datum. The results of data collection conducted can be described as follows: 


\section{Respondents Identity}

Table 1. Gender, AgeandEducation Level

\begin{tabular}{cccccccc}
\hline \multicolumn{2}{c}{ Gender } & & Age & & \multicolumn{3}{c}{ Education } \\
M & F & $<43$ & $44 \leq 64$ & $65>$ & $\begin{array}{c}\text { Elementary } \\
\text { Shcol/lunior } \\
\text { High School }\end{array}$ & $\begin{array}{c}\text { Senior } \\
\text { High } \\
\text { School }\end{array}$ & Undergraduate \\
15 & 17 & 20 & 10 & 2 & 17 & 14 & 1 \\
$47 \%$ & $53 \%$ & $63 \%$ & $31 \%$ & $6 \%$ & $53 \%$ & $44 \%$ & $3 \%$ \\
\hline
\end{tabular}

\section{Data Analysis}

1. Context Dimension

In relation to the context dimension of the evaluation of mentoring programs in improving the livelihoods of small and medium entrepreneurs community, it shows that the surrounding environmental problems, based on the data obtained where for the environment in the evaluation included in the "appropriate" category that is as much as $78 \%$, and 'less appropriate' as much as $22 \%$.

2. Input Dimensions include: (1) Assisstants' Duties and Responsibilities, based on data that the assistants'duty is to motivate the participants included in the "appropriate" category of $81 \%$, "less appropriate" by $19 \%$. And (2) Media of Mentoring Program, based on data that the media of mentoring program included in the "appropriate" category as much as $75 \%$, and "less appropriate" as much as $25 \%$.

3. Process dimensions include: (1) Time of Mentoring, based on the data that the assessment of the time of mentoring is included in the "appropriate" category as much as $81 \%$, and "less appropriate" as much as $19 \%$. (2) Types of Mentoring Activities. Based on the data that the assessment of the type of assistance activities included in the "appropriate" category as much as $78 \%$, and "less appropriate" as much as $22 \%$. (3) Mentoring Methods and Techniques. Based on the data that the assessment of the methods and techniques of mentoring included in the "appropriate" category as much as $100 \%$. (4) Mentoring material.

Based on the data that the assessment of mentoring material included in the "appropriate" category as much as $100 \%$. (5) Compatibility of Methods with Characteristics of Participants. Based on the data that the assessment of the suitability of the method with the characteristics of participants included in the "appropriate" category is as much as $78 \%$, and "less appropriate" is as much as
22\%. (6) Mentors Attendance Level.

Based on the obtained data, the assessment towards the presence of the mentors is included in the "appropriate" category as much as $94 \%$ and "less appropriate" as much as $6 \%$.

4. Product Dimension Encompasses:

(1) Entrepreneurial Innovation Skills. Based on data that the assessment of entrepreneurship innovation skills included in the "appropriate" category is as much as $78 \%$, and "less appropriate" is as much as $22 \%$.

(2) The Level of Knowledge of Entrepreneurship. Based on data that the assessment of entrepreneurship level of knowledgeincluded in the "appropriate" category is as much as $75 \%$, and "inappropriate" is as much as $25 \%$.

(3) Productivity. Based on the data that the assessment of productivity included in the "appropriate"category is as much as $69 \%$, and "less appropriate" is $31 \%$.

(4) Making business more smoothly, based on data that the assessment of business that works more smoothly included in the corresponding category as much as $97 \%$, and "less appropriate" as much as $3 \%$.

(5) Financing skills. Based on the data that the assessment of financial bookkeeping included in the "appropriate" category is as much as $72 \%$, and "less appropriate" is $28 \%$.

(6) Business Management Skills, based on data that the assessment of business management skills included in the "appropriate" category of $66 \%$, and "less appropriate" as much as $34 \%$.

(7) Self-Esteem. Based on the data that the assessment of the mentoring participants' selfconfidence included in the corresponding category is as much as 69\%, and "less appropriate" is $31 \%$.

(8). The spirit of entrepreneurship, based on the data that the assessment of entrepreneurship spirit included in the category "appropriate" as much as 94\%, and "less appropriate" as much as 6\%.

(9) Reliability in Entrepreneurship. Based on data that the assessment of reliability in entrepreneurship included in the "appropriate" category is as much as 64\%, and "less appropriate" is as much as $31 \%$.

(10) Entrepreneurship Knowledge. Based on the data that the assessment of entrepreneurship knowledge included in the corresponding category is as much as $62 \%$, and "less appropriate" is $38 \%$.

(11) Self-introspection of the Mentoring Participants, based on data that the assessment 
of self-introspection is included in the "appropriate" category of $91 \%$, and "less appropriate" by $9 \%$.

(12) Participants' Independence. Based on the data that the assessment of the mentoring participants' independence included in the corresponding category is as much as $62 \%$, and "less appropriate" is as much as $38 \%$.

(13) The Income of Mentoring Participants. Based on the data that the assessment of the income of the mentoring participants included in the "appropriate" category is as much as $66 \%$, and "less appropriate" is as much as $34 \%$.

(14) Economic improvement of mentoring participants. Based on the data that the assessment of economic improvement included in the corresponding category is as much as $97 \%$, and "less appropriate" is as much as $3 \%$. And,

(15) The welfare level of the mentoring participants. Based on the data that the assessment of welfare level included in the "appropriate" category is as much as $78 \%$, and "less appropriate" is $22 \%$.

\section{Research Discussion}

Important evaluation is omitted in order to know the effectiveness of the implementation of business assistance program for Community-Based Livelihood Improvement (PPMbK) In CipinangMuara, East Jakarta. The evaluation implementation can be viewed in terms of context, input, process and product by using the CIPP evaluation model developed by Stuffebeam. The implementation of the evaluation of community-based livelihood assistance improvement program (PPMBK) is measured from the context evaluation or background information, program objectives, program indicators and problems in the environment. Input evaluation examines data on the use of resources that support the mentoring program. Evaluation of the process of reviewing data on the implementation of business assistance programs forthe Community-Based Livelihood Improvement. Product evaluation measures and interprets whether the results of the assistance in accordance with the objectives of the program has been established.

\section{a. Context}

Based on the results of the context component, it shows that the background of the community-based livelihood support program (PPMBK) is there are many business actors, whether micro or macro, have various obstacles in running their business. Besides, due to the limited capital and their knowledge about entrepreneurship is also very limited. The purpose of the program is to help improving the livelihood of the businesspersons who have problems in running their business. In addition, it is also primarily to assist PS2-based community or less well-off communities as an opportunity to open employment in order to reduce urban unemployment through sustained assistance that is adapted to the appropriate needs.

The goal of this program is primarily to PS2-based or lower-middle-class communities on the condition that they have a business. The success indicators of this program are increasingly productive business actors whose business is getting smoother, their income, and their level of knowledge about entrepreneurshipare increasing. This mentoring program was introduced to the community through socialization in the purposed village and also Forum Group Discussion (FGD) in the local community.

\section{b. Input}

Based on the results of the input component, the companion is recruited through deliberations within the local community with criteria such as their social, honesty, trustworthy, responsibility, patience, and assistance ability. This is reinforced by the accompanying statement that their motivation to be a companion in this program is as a sense of concern for the surrounding community to help their problems. In addition, their experience before becoming a companion in this program is to accompany the cooperative shariahbaitulmaalwattamwil in the Small Incubation Center KebonSirih area, became the chairman of the assemblies taklim and now the village chief or RW.

In addition, the companion also understands that thier main duties and responsibilities in this program is assisting, supervising, directing and motivating the members of KSM. The requirement to become a member of KSM is primarily running a business, but for those who have not or do not have a business they can join others to create business group together. All of the requirements must be included in the proposal to specify the adjustment of loan funds.

The numbers of KSM assisted by the assistants are 10 SHGs with the provision of one KSM should consist of at least 5 members 
and a maximum of 15 members. The place of mentoring activity is carried out in POS RW 02 , but since the operational cost given is limited, then the assistance can not use special media such as LCD. Instead,the media used are microphone and sound.

\section{c. Process}

The results obtained from this process component is the accompaniment of the routine that is being conducted and mutual help in entrepreneurship, spiritual appreciation in entrepreneurship, and giving guidance on how to promote a good and right business product. Another result is the guidance on business management. The attendance of $\mathrm{KSM}$ members in the mentoring activities is usually about $80 \%$. Not only in the afternoon but there are members of KSM who also run night operations. The companion also came relatively on time in the mentoring activities.

And, the interaction process between the KSM members and the consultants. In overcoming the obstacles that occur during the mentoring is usually escorted from one house of KSM member to anothers. The opponent of each KSM chairman is an organizer to discuss, solve problems and look for alternatives together. The companion is also fairly patient in assisting the KSM members.

\section{d. Product}

Based on the results obtained from the product component, the results of business assistance programs for the CommunityBased Livelihood Improvement (PPMBK) sufficiently perceived by KSM members as the participants. From the questionnaire filled by the respondents, the majority of KSM members experiencean improvement in terms of skills and knowledge about entrepreneurship, productivity, tackiness in business management, self-development, welfare, and independence. However, based on the questionnaire results, there are still some KSM members who do not feel the maximum benefits in any of those aspects. Nevertheless, in the loan refund, there are still many KSM members who are frequently late in repaying the capital loan of business funds due to the lack of discipline.

\section{CONCLUSION}

Based on the results of the research, the effectiveness of business assistance programs for the Community-Based Livelihood Improvement (PPMbK) in CipinangMuara, East Jakarta is concluded here. Based on the component of the Context, Input, Process, and Product (CIPP), it indicates that the implementation of PPMBK business assistance program is right and in accordance with the needs of KSM as the target. This is evidenced from the results of data analysis of the questionnaires that have been filled by the KSM members and show an effective result.

Based on the results of the interviews, itindicates that many of the mentoring members of the KSM feel the impact and benefits of the activities. This is evidenced by the increasing number of KSM members who are more careful in maintaining the cleanliness of their business products, such as selecting fresh raw materials in the manufacture of products / processed products and avoiding the use of chemicals that could endanger the consumers' health. Additionally, the KSM members also become more familiar with financial and accounting matters which affect the number or percentage of the KSM members who repay the loan funds on time.

The innovations shown by the KSM members such as ketoprak traders who repainted their carts and rice-cookers as well ascreated banners with the labeled identities built by LKM CipinangMuara in order to attract more consumers. The KSM members are also increasingly instilling principle of honesty in running their business. Furthermore, there are some KSM members who have been said to be more self-sufficient such as ketoprak, satay, pece catfish, and meatballs sellers.

Then, there are the constraints found as the program evaluation, ie the mechanism of companion recruitment that is less efficient. The reason standing behind this issue is that companion recruited by the $\mathrm{P} 2 \mathrm{KP}$ is not the person assigned specifically to provide assistance, but only the elected community leaders based on deliberation in the local area. As a result, the companion did not have much time to accompany the KSM members due to their main work routine. In addition, the amount of allocated budget is limited causing the implementation of the assistance program did not run optimally.

Therefore, the conclusion of this research is that the implementation of Community Based Livelihood Improvement program (PPMbK) in KelurahanCipinangMuara, East Jakarta is considered effective based on the 
evaluation result by using CIPP evaluation model.

\section{REFERENCES}

[1] Arikunto, Suharsimi. (2009). Evaluasi Program Pendidikan, Pedoman Teoritis Praktis Bagi Mahasiswa dan Pendidikan. Jakarta: Bumi Aksara.

[2] --------, ( 2010). Prosedur Penelitian, Suatu Pendekatan Praktik. Jakarta: Rineka Cipta.

[3] Alma, Buchari. (2009). Kewirausahaan. Bandung: Alfabeta.

[4] Badan Pusat Statistik. Indikator Garis Kemiskinan, (Online), (https://www.bps.go.id, diakses 8 April 2016).

[5] Christie, T. (2009). Why school based assessment is not a universal feature of high stakes assessment systems? : The Journal of Educational Assessment, Evaluation and Accountability Dordrecht: Vol . 21(4): 329

[6] Datta, L. E. (2001). Coming attractions.American Journal of Evaluation, 22(3), 403-408.

[7] Hadeli. (2006). Metode Penelitian Kependidikan. Padang: Quantum Teaching

[8] Homan Madeleine \& Miller J Linda. (2008). Coaching in Organizations: BestChoaching Practices from The Ken Blanchard Companies. NewYork: JWP.

[9] Huda Miftahul. (2009). Pekerjaan Sosial \& Kesejahteraan Sosial. Yogyakarta: Pustaka Pelajar.

[10] Jahanian, R. (2012) : Educational Evaluation: Functions and Applications in Educational Contexts.International Journal of Academic Research in Economics and Management Sciences, Vol. 1, No. 2 hal. 253-257

[11] Johnson, R. L., McDaniel, F., \& Willeke, M. J. (2000). Using portfolio's in program evaluation: an investigation of interrater reliability. American Journal of Evaluation, 21(1), 65-80.

[12] Sudjana Djudju. (2009). Evaluasi Program Pendidikan Luar Sekolah UntukPendidikan Nonformal Dan Pengembangan Sumber Daya Manusia. Bandung: Rosda.

[13] Sugiyono. (2010). Metode Penelitian Pendidikan (Pendekatan Kuantitatif,Kualitatif, dan R\&D). Bandung: Alfabeta.

[14] Sukardi. (2003). Metodologi Penelitian Pendidikan, Kompetensi dan Praktiknya. Jakarta: Bumi Aksara

[15] Sumodiningrat. (2009). Mewujudkan Kesejahteraan Bangsa: Menanggulangi Kemiskinan dengan Prinsip Pemberdayaan Masyarakat. Jakarta:PT. Alex Media Komputindo.

[16] Sutisna, Anan dan Vibriyanthy Rica. (2010). Evaluasi Program Pendidikan Kesetaraan Paket C Di Lembaga Permasyarakatan Klas I CipinangJakarta Timur,"Jurnal Pendidikan Masyarakat Indonesia Volume 12Tahun IV, April 2010.

[17] Suud, Muhammad. (2006). Tiga Orientasi Kesejahteraan Sosial. Jakarta: Prestasi Pustaka.

[18] Tognolini, J. Stanley,G. (2007). Standards-based assessment a tool and means to the development of capital and capacity building in education :The Australian Journal of Education. Camberwell. Vol. 51 (2) : 129

[19] Usman, Husaini dan Akbar Setiady Purnomo. (2011). Metodologi PenelitianSosial. Jakarta: Bumi Aksara

[20] Pratt, C. C., McGuigan, W. M., \& Katzev, A. R. (2000). Measuring program outcomes: Retrospective pretest methodology. American Journal of Evaluation, 21(3), 341-349.

[21] Yusuf, Syahrial. (2010). Entrepreneurship, Teori dan Parktik Kewirausahaan Yang Telah Terbukti. Jakarta: Lentera Ilmu Cendikia. 